War and Autocephaly in Ukraine

Author(s): Cyril Hovorun

Source: Kyiv-Mohyla Humanities Journal 7 (2020): 1-25

Published by: National University of Kyiv-Mohyla Academy

http://kmhj.ukma.edu.ua/ 


\title{
War and Autocephaly in Ukraine
}

\author{
Cyril Hovorun \\ Stockholm School of Theology
}

\begin{abstract}
A series of conflicts that followed the collapse of the Soviet Union culminated in the war in Ukraine waged by Russia in 2014. The international community was taken by surprise, and its reactions to the Russian aggression were often confused and inadequate. Even more confused and inadequate were the responses from global Christianity. Russian propaganda often renders the aggression against Ukraine as a quasi-religious conflict: a "holy war" against the "godless" or "heterodox" West. It would be natural, therefore, for the Christian churches worldwide to loudly condemn both propaganda and aggression. However, in most cases, their response was silence. Such reactions came from most local Orthodox churches, the Roman Catholic church, and international ecumenical organizations such as the World Council of Churches. An exception was the reaction from the Ecumenical Patriarchate, which decided to grant autocephaly to the Orthodox Church of Ukraine. The article argues that the Tomos for autocephaly was, among other reasons, a reaction to the war in Ukraine. The responses of other local Orthodox churches to the Tomos also indicate their attitude to the war in Ukraine. These reactions have demonstrated a profound crisis in inter-Orthodox solidarity and social ethics.
\end{abstract}

Key Words: war, church diplomacy, Tomos, autocephaly, the Ecumenical Patriarchate, the Orthodox Church of Ukraine.

\section{(2)}

\section{Casus Belli}

The collapse of the Soviet Union in 1991 did not cause immediate full-scale wars between Russia and the independent states that emerged from the USSR. There were some military conflicts on the post-Soviet periphery, such as between Armenia and Azerbaijan over the disputed region of Nagorno-Karabakh (Artsakh) in 1991-1994 and recently in 2020, in Tajikistan in 1992-1997, in the Georgian regions of South Ossetia and Abkhazia in 1991-1993 and later in 1998, in the Moldovan region of Transnistria in 1990-1992. Although Russia had hidden involvement in most of these conflicts, it acted mostly through its proxies, not directly.

The first open intervention of Russia in another post-Soviet state happened in August 2008 in the Republic of Georgia. As a result of this intervention by regular Russian troops, Georgia lost control over twenty percent of its territory. Russia's war against Georgia was not adequately evaluated and addressed by the West. This encouraged Russian President Vladimir Putin to attempt to wage a war of a much larger scale. He launched such a war against Ukraine after the victory of the Revolution of 
Dignity in 2014. Russian military troops first annexed the Crimean Peninsula and then, assisted by local collaborators, entered Ukraine on its eastern border. Putin planned to establish Russian control over the entire Southeast of the country in order to make a corridor to Crimea. However, because of the resistance of the Ukrainian army and volunteer battalions, the Russians, together with local separatists, managed to occupy only some parts of the Donetsk and Luhansk regions.

The human cost of the war is enormous. According to the report of the United Nations Office for the Coordination of Humanitarian Affairs,

in its seventh year, the conflict in Donetska and Luhanska oblasts in eastern Ukraine continues to significantly impact the lives of more than five million people living in the region, 3.4 million of whom require humanitarian assistance and protection services. Since the start of the conflict in 2014, more than 3,350 civilian men, women and children have been killed and another 7,000 have been injured. As the crisis persists, civilians continue to bear the brunt of the conflict. Fear of shelling, violent clashes, and the threat of landmines and explosive remnants of war are the daily reality for millions of people living on both sides of the more than 420 kilometer-long "contact line" - equivalent to the length of the French-German border. Today, eastern Ukraine is considered one of the most mine-contaminated areas in the world. ${ }^{1}$

The war claimed around 13 thousand lives, of whom one third are civilians. Over 3 o thousand people have been wounded. ${ }^{2}$ Among the war victims are 283 passengers and 15 crew members of a Malaysia Airlines flight from Amsterdam to Kuala Lumpur (MH17), which was shot down on July 17, 2014. The Joint Investigation Team (JIT), led by the Dutch government, established that the plane was shot down by the sophisticated Buk Russian military anti-aircraft missile system, which was brought from Russia to Ukrainian territory controlled by the separatists. ${ }^{3}$ There is another outcome of the war, which has to do with severe violations of human rights by Russia. There are over

"Ukraine. Situation Report," United Nations Office for the Coordination of Humanitarian Affairs, last updated October 27, 2020, accessed December 5, 2020, https://tinyurl.com/y4902qov. Christopher Miller, "13 tysiach: ofitsiini dani OON shchodo zahyblykh u viini na Donbasi [13 Thousand: Official UN Data on Those Killed in the War in the Donbas]," Radio Svoboda, 26 February, 2019, accessed December 5, 2020, https://tinyurl.com/y6xw27w9.

3 Dutch foreign minister Stef Blok made a statement after the JIT finished its investigation: "On the basis of the JIT's conclusions, the Netherlands and Australia are now convinced that Russia is responsible for the deployment of the Buk installation that was used to down $\mathrm{MH}_{17}$. The government is now taking the next step by formally holding Russia accountable." See "MH17: The Netherlands and Australia Hold Russia Responsible," Government of the Netherlands, May 25, 2018, accessed December 5, 2020, https://tinyurl.com/y38nhcn2. 
five thousand Ukrainians held for political reasons in prisons in Russia and occupied Crimea. ${ }^{4}$ The best known political prisoner was Ukrainian film director Oleg Sentsov. He was arrested in Crimea for opposing its annexation and sentenced by a Russian court to twenty years in prison (subsequently released in 2019 in a prisoner exchange).

\section{Reactions of the International Community}

The aggressive activities of Russia against Ukraine took the international community by surprise. Most international organizations and states expressed their support to Ukraine, even though it was more in words than in deeds. Still, the words were clear and quite strong. Thus, soon after the annexation of Crimea, the General Assembly of the United Nations discussed and adopted on March 27, 2014, a resolution, which confirmed that the peninsula continues to belong to Ukraine. 100 countries voted for the resolution, 11 against, and $5^{8}$ abstained. ${ }^{5}$ The U. N. also strongly condemned the downing of flight MH17. This issue was discussed by the Security Council, which adopted on July 21, 2014, a relevant resolution. ${ }^{6}$ The identification and condemnation of the Russian aggression against Ukraine was never an easy task in the United Nations. As a permanent member of its Security Council, Russia has the right to veto any of its decisions. It has often used this right to block decisions in favor of Ukraine. ${ }^{7}$

The European Parliament is less restricted in standing up to Russia. It adopted a series of resolutions that supported the integrity of Ukraine and condemned the Russian aggression against it. For instance, in its resolution on September 18, 2014, it declared that it "strongly condemns the Russian Federation for waging an undeclared 'hybrid war' against Ukraine with use of regular Russian forces and supporting illegally armed groups." 8 The European Parliament also systematically addressed the issue of human rights on the Ukrainian territories occupied by Russian or pro-Russian forces. ${ }^{9}$ In particular, it condemned the imprisonment of Oleg Sentsov and demanded that Russia

See information from the office of the Ukrainian Parliament Commissioner for Human Rights available at http://www.ombudsman.gov.ua/ua/page/secretariat/gromadskist/ukraiinskipolitvyazni.html.

UN General Assembly Resolution 68/262, Territorial Integrity of Ukraine, A/RES/68/262, March 27, 2014, accessed December 5, 2020, https://tinyurl.com/y55fo8dz.

UN Security Council Resolution 2166 (2014), S/RES/2166 (2014), July 21, 2014, accessed December 5, 2020, https://tinyurl.com/yxvb5 $x_{3} 6$.

Such as, for example, UN Security Council draft resolution S/2014/189 on March 15, 2014, accessed December 5, 2020, https://tinyurl.com/y2olofp9.

8 European Parliament Resolution 2014/2841 (RSP), On the Situation in Ukraine and the State of Play of EU-Russia Relations, September 18, 2014, P8_TA(2014)oO25, accessed December 5, 202O, https://tinyurl.com/y2afpumg.

9 European Parliament Resolution 2016/2556 (RSP), On the Human Rights Situation in Crimea, in Particular of the Crimean Tatars, February 4, 2016, P8_TA(2016)o043, accessed December 5, 2020, https://tinyurl.com/y48zahgf. 
release him. ${ }^{10}$ The E. U. also imposed economic sanctions on Russia as an instrument of political pressure.11

Even more restrictive have been the measures taken against Russia by the United States of America. ${ }^{12}$ All branches of government in the United States adopted numerous decisions and resolutions condemning Russian aggression against Ukraine. For example, a resolution sponsored by Rep. Ted Poe (R-TX-2) addressed the territorial integrity of Ukraine, Georgia, and Moldova (whose Transnistria territory is controlled by a Russianbacked political regime). Among other statements, it called "the Russian Federation to immediately cease its military support to illegal paramilitary units operating within the internationally recognized territories of Ukraine, Georgia, and Moldova," to "cease its destabilizing activities in Transnistria in Moldova, South Ossetia and Abkhazia in Georgia, and the Donetsk and Luhansk oblasts of Ukraine, as well as to terminate its forcible and illegal annexation of Crimea." ${ }^{13}$

\section{Reactions of Churches in Ukraine}

There is an interfaith network in Ukraine, which has issued equally strong messages regarding the Russian aggression. It is the All-Ukrainian Council of Churches and Religious Organizations (AUCCRO), an independent ecumenical platform, where representatives of the Christian, Jewish, and Muslim communities regularly meet together and discuss issues important for them and for the entire Ukrainian society. The AUCCRO was established in 1996 on an initiative of President Leonid Kuchma (1994-2005). Soon, however, the council became independent from the state and now functions in the capacity of a non-governmental organization. It constitutes one of the most successful examples of inter-Christian and inter-faith cooperation in Europe. Even when churches or religious organizations hesitate to speak up on their own regarding various public or religious issues, they use the AUCCRO platform to unite their voices with other groups in advocating for common causes.

Since the beginning of the protests at the Maidan in December 2013, the AUCCRO has repeatedly urged Ukrainian authorities to avoid violence against peaceful

10 European Parliament Resolution 2018/2754(RSP), On Russia, Notably the Case of Ukrainian Political Prisoner Oleg Sentsov, June 14, 2018, P8_TA(2018)o259, accessed December 5, 202O, https://tinyurl.com/yxo8v8zv.

11 See "EU Restrictive Measures in Response to the Crisis in Ukraine," Delegation of the European Union to Russia, August 10, 2017, accessed December 5, 2020, https://tinyurl.com/y6noddxy.

12 See their list on the website of the US Department of State: https://www.state.gov/ukraine-andrussia-sanctions/.

13 US House of Representatives, Resolution Affirming United States Support to the Nations of Ukraine, Georgia, and Moldova in Their Effort to Retain Political Sovereignty and Territorial Integrity, June 2O, 2018, 115th Cong., 2nd sess., H. Res. 955, accessed December 5, 2020, https:// tinyurl.com/y2hhqoke. 
protesters. ${ }^{14}$ After the first casualties at the Maidan, the members of the AUCCRO stepped in and offered mediation between the leaders of the Maidan and the government. ${ }^{15}$ When Ukrainian President Viktor Yanukovych was ousted, and Oleksandr Turchynov replaced him as acting president, the members of the AUCCRO met with the acting president. After the meeting, they issued a public statement in which they recognized the transition of political power as legitimate. ${ }^{16}$

On March 1, 2014, the Russian Federation Council voted to grant permission to use Russian military forces against Ukraine. In response to this decision, which effectively opened the door for a declaration of war, the AUCCRO issued a statement addressed to Russian authorities. It urged them

to give up military or any other interference into the internal affairs of Ukraine that are not provided by international law and bilateral agreements. The Russian authorities ought to realize their responsibility before God and mankind for possible irrecoverable consequences of the military conflict on Ukrainian territory.17

During the years of the war that followed, the AUCCRO repeatedly addressed humanitarian issues, which emerged as a result of Russian aggression. The Council supported the self-defense of Ukraine ${ }^{18}$ and urged Russia to release hostages and

14 "Zvernennia Vseukrainskoi Rady Tserkov u zviazku z suspilno-politychnoiu sytuatsiieiu v Ukraini [Statement of the All-Ukrainian Council of Churches Regarding the Social and Political Situation in Ukraine]," VRTSIRO, December 10, 2013, accessed December 5, 2020, https://tinyurl. com/y5y6pkal; “Zvernennia Vseukrainskoi Rady Tserkov z nahody Dnia Sobornosti ta Svobody Ukrainy [Statement of the All-Ukrainian Council of Churches on Occasion of the Ukrainian Unity and Liberty Day]," VRTsIRO, January 22, 2014, accessed December 5, 2020, https://tinyurl. com/yyqb6fkg.

15 "Rada Tserkov zaklykaie vidnovyty konstytutsiinyi lad ta povnotu prav i svobod hromadian (zaiava) [The Council of Churches Calls for the Restoration of the Constitutional Order and the Fullness of Citizens' Rights and Freedoms (Statement)]," Instytut Relihiinoi Svobody, January 25, 2014, accessed December 5, 2020, https://tinyurl.com/y4ckzjno.

16 "Zaiava za pidsumkamy zustrichi z kerivnytstvom Verkhovnoi Rady Ukrainy [Statement Following the Meeting with the Leadership of the Verkhovna Rada of Ukraine]," VRTsIRO, February 26, 2014, accessed December 5, 2020, https://tinyurl.com/y6rgyam6.

"Zaiava Rady Tserkov shchodo rishennia Rosii pro viiskove vtorhnennia v Ukrainu [The Council of Churches Statement on Russia's Decision on the Military Invasion of Ukraine]," VRTsIRO,

March 2, 2014, accessed December 5, 2020, https://tinyurl.com/y43vsd72.

18 "Zvernennia Vseukrainskoi Rady Tserkov i relihiinykh orhanizatsii pro oboviazok dopomohy u zakhysti Batkivshchyny [Appeal of the All-Ukrainian Council of Churches and Religious Organizations on the Obligation to Assist in the Defense of the Motherland]," VRTsIRO, February 10, 2015, accessed December 5, 2020, https://tinyurl.com/y4ukkmh7. 
prisoners of war, ${ }^{19}$ as well as political activists. ${ }^{20}$ It also encouraged the faithful of its member churches and religious groups to become volunteers ${ }^{21}$ and inspired the volunteers to visit and bring relief to soldiers and civilians on the front line. ${ }^{22}$

In coherence with the statements promulgated by the All-Ukrainian Council of Churches and Religious Organizations, its two Orthodox members, namely the Patriarchate of Kyiv and the Ukrainian Autocephalous Orthodox Church, produced their own statements. They explicitly condemned the Russian aggression against Ukraine and provided relief to those affected by the war. In contrast to them, the largest Orthodox jurisdiction in Ukraine, the Ukrainian Orthodox Church (UOC), which is in unity with the Moscow Patriarchate, refused to acknowledge the Russian aggression and instead systematically used euphemisms to avoid calling it such. ${ }^{23}$ This policy dramatically contrasted with the policies of other Ukrainian Orthodox churches, and even with its policies in the first months of the Russian aggression. Thus, at the beginning of March 2014, the locum tenens of the Kyivan see, Metropolitan Onufriy, later elected the Primate of the UOC, publicly urged the Patriarch of Moscow and the President of Russia to stop the Russian intervention in Ukraine. ${ }^{24}$

The rhetoric of the UOC denying the war also went against the positions of the same church in the frame of the All-Ukrainian Council of Churches and Religious Organizations. The presidency in the AUCCRO rotates every half year. During the period of the Maidan and at the beginning of the Russian aggression, it was the turn of the Ukrainian Orthodox Church under the Moscow Patriarchate to preside at meetings

19 "Rada Tserkov zaklykaie zvilnyty zaruchnykiv z polonu na Donbasi [The Council of Churches Calls for the Release of Hostages From Captivity in the Donbas]," VRTsIRO, September 8, 2016, accessed December 5, 2020, https://tinyurl.com/y6e6c9w9.

20 "Rada Tserkov hotuie zvernennia na pidtrymku ukrainskikh viazniv Kremlia [The Council of Churches is Preparing an Appeal in Support of Ukrainian Kremlin Prisoners]," Religion in Ukraine, June 13, 2018, accessed December 5, 2020, https://tinyurl.com/y2puawnu.

"Zvernennia Vseukrainskoi Rady Tserkov na pidtrymku blahodiinytstva i volonterskoi dialnosti [Appeal of the All-Ukrainian Council of Churches and Religious Organizations for the Support of Charity and Volunteer Activity]," VRTsIRO, October 31, 2014, accessed December 5, 2020, https://tinyurl.com/y5fdqgdx.

"Zvernennia Vseukrainskoi Rady Tserkov i relihiinykh orhanizatsii [Appeal of the All-Ukrainian Council of Churches and Religious Organizations]," VRTsIRO, April 12, 2017, accessed December 5, 2020, https://tinyurl.com/y2uep3dy.

23 See for example the interview of the official speaker of this church Bishop Klyment (Vecheria): Hromadske, "Yepyskop Klyment: Vladyka Pavlo ne kupuvav sobi avto ta maietok—tse pozhertvy [Bishop Klyment: Bishop Pavlo Did Not Buy Himself a Car and an Estate-These are Donations]," YouTube Video, 55:35, October 8, 2015, accessed December 5, 2020, https://tinyurl. com/yyezsegc. kafedry [The Address of Metropolitan Onufriy, Acting Head of the Kyivan See]," YouTube Video, 5:O2, March 2, 2014, accessed December 5, 2020, https://tinyurl.com/y279ngvw. 
of the council and to sign statements on behalf of all members. Thus, critical AUCCRO documents supporting public protests, urging the Yanukovych government to avoid violence, and condemning Russia for its intervention, were signed by representatives of the Moscow Patriarchate in Ukraine.

\section{Reactions from Global Orthodoxy}

Official statements of the UOC (in contrast to its signatures under the statements of the AUCCRO) did not significantly differ from statements of the Russian Orthodox Church. This church did not keep silent on the war in Ukraine. On the contrary, it developed a narrative to explain the war to its faithful. According to this narrative, the Revolution of Dignity was a rebellion against the lawful government of President Yanukovych. The president and government that succeeded them are not legitimate. The Maidan reoriented Ukrainian society from the allegedly "holy Russia" to the allegedly "godless West." The war in the East of the country became a reaction to the u-turn that Ukrainian society made towards the West. Its primary cause was to protect the Christian values of Russia against the allegedly anti-Christian corruption of values coming from the West.

Nota single statement promulgated by the Russian Orthodox Church acknowledged Russian involvement in the war. Instead, these statements insistently applied to the war the ambivalent euphemism of "fratricide." This word, on the one hand, implies a fight between brothers in faith, regardless of their nationality. Indeed, the majority of those fighting in the East of Ukraine, on both sides, are Orthodox Christians. However, spokesmen of the Russian church insist that the pro-Ukrainian side of the war is not Orthodox but predominantly Uniate. From the Russian position, Uniates are not brothers in Christ of those fighting on the pro-Russian side of the conflict. The word "fratricide" from the Russian point of view, therefore, implies peoples of the same nationality. This euphemism became a synonym for civil war and is propagated by the Kremlin through the Russian media. In tune with this propaganda, the Patriarch of Moscow Kirill introduced a special prayer about Ukraine in all churches of the Moscow Patriarchate:

O Lord Jesus Christ our God, look down with your merciful eye upon the sorrow and painful cry of your children, who are in Ukrainian lands. Deliver your people from the civil strife, quench the bloodshed, divert the ongoing misfortunes. House those deprived of roofs over their heads, feed the hungry, console those who cry, unite those who are divided... ${ }^{25}$ 
While encouraging the faithful to pray for the undoubtedly good cause of charity, the prayer also makes them perceive the war as civil—one of the main points of Russian propaganda. The prayer, thus, was itself transformed into an instrument of propaganda. Even the humanitarian aid offered by the Russian church to those in need in the East of Ukraine was not wholly free from political bias. It went to only one side of the conflict, which is pro-Russian. It should be acknowledged, though, that the Ukrainian Orthodox Church of the Moscow Patriarchate offered humanitarian aid to both sides of the conflict. In its rhetoric, however, as it was mentioned, it was coherent with the narratives produced by the Russian Orthodox Church.

The standpoint of the Russian church regarding the annexation of Crimea is as ambivalent as its words and deeds regarding the war in the Donbas. On the one hand, the Moscow Patriarchate kept the dioceses in Crimea under the jurisdiction of Kyiv. The Crimean bishops attend the sessions of the Holy Synod of the Ukrainian Orthodox Church. It should also be noted that the Patriarch did not attend President Vladimir Putin's reception on the occasion of the annexation of Crimea on March 18, 2014. The Patriarch did not show up in the Kremlin for this occasion not because he disagreed with the Kremlin, but because both the church and the Kremlin did not want to give Constantinople an excuse to intervene in the Ukrainian situation.

In contrast to the Russian Orthodox Church, which often spoke on Ukraine, always in coherence with the Kremlin, the rest of the Orthodox churches kept silent. Their silence is as disturbing as the many words uttered by the Russian church. They have consistently ignored both wars on the European continent that involve Orthodox nations, in Georgia and Ukraine. They even failed to address the humanitarian crises caused by these wars. The silence of the Orthodox churches on the European wars that involved Orthodox nations has demonstrated a considerable deficiency of Panorthodox unity and solidarity.

At the same time, to some Orthodox churches and hierarchs, the war gave an opportunity to blame the West and the Catholic church in particular. The narrative of the Russian church that put all blame for the Ukrainian revolution and war on the Greek Catholics was accepted by those who believe in the Catholic conspiracy against the Orthodox. A disturbingly large number of Orthodox hierarchs, clergy, and faithful have interpreted the war in Ukraine as a conflict between the Orthodox and Catholic churches. Some leaders of Orthodox and Catholic churches realized the danger for their relations coming from such misinterpretations of the reasons for the Ukrainian war. When Pope Francis and Patriarch Bartholomew met in Istanbul in November 2014, they issued a joint statement, where they gently touched on this issue:

We also remember all the people who experience the sufferings of war. In particular, we pray for peace in Ukraine, a country of ancient Christian tradition, while we call upon all parties involved to pursue the path of dialogue and of respect for international law 
in order to bring an end to the conflict and allow all Ukrainians to live in harmony. ${ }^{26}$

In the same statement, the Pope and the Ecumenical Patriarch said much more about the conflicts in the Middle East. Nevertheless, even this laconic phrase in the statement revealed more about the nature of the conflict than any other Orthodox church. In particular, their call to respect international law was a clear reference to the decisions of the international community, which condemned the annexation of Crimea and the Russian-backed war in the East of Ukraine.

\section{Reactions from the Roman Catholic Church}

The Istanbul declaration chartered a general framework for Pope Francis's following rhetoric on Ukraine. This rhetoric stresses the need for peace and reconciliation. It occasionally invokes the need to restore international order but never blames Russia for what has happened. Such was, for instance, one of his messages Urbi et Orbi for the Easter of 2015:

May the Lord's resurrection bring light to beloved Ukraine, especially to those who have endured the violence of the conflict of recent months. May the country rediscover peace and hope thanks to the commitment of all interested parties. ${ }^{27}$

In a few cases, Pope Francis's language turned from vague to ambivalent. During one of his general audiences, for example, he called the war in Ukraine by a term from the vocabulary of Russian propaganda: fratricide. ${ }^{28}$

Pope Francis was more cautious in choosing words for the declaration that he signed together with the Patriarch of Moscow and all Russia Kirill in Havana, Cuba, where they met on February 12, 2016. The declaration called upon the sides of the conflict for dialogue and reconciliation:

We deplore the hostility in Ukraine that has already caused many victims, inflicted innumerable wounds on peaceful inhabitants and thrown society into a deep economic and humanitarian crisis. We invite all the parts involved in the conflict to prudence,

26 "Apostolic Journey of His Holiness Pope Francis to Turkey: Ecumenical Blessing and Singing of the Common Declaration," The Holy See, November 30, 2014, accessed December 5, 2020, https://tinyurl.com/y2bagdoj.

27 "Urbi et Orbi Message of His Holiness Pope Francis (Easter 2015)," The Holy See, April 5, 2015, accessed December 5, 2020, https://tinyurl.com/y3tl5ght.

28 "Pope Decries 'Fratricide' Conflict in Ukraine and Appeals for Dialogue," Vatican Radio, February 4, 2015, accessed December 5, 2020, https://tinyurl.com/y29sagh6. 
to social solidarity and to action aimed at constructing peace. We invite our Churches in Ukraine to work towards social harmony, to refrain from taking part in the confrontation, and to not support any further development of the conflict. ${ }^{29}$

It should be noted that in this statement, the war in Ukraine was not called "civil," even though earlier in the same text, the conflicts in the Middle East were characterized as civil. ${ }^{30}$ Those who were close to the process of drafting the document have informed the author of this article that the original draft of the declaration, which was prepared in collaboration with the Russian side, contained the word "civil" in application to the war in Ukraine. It was, however, eliminated in the last moment of preparations, on the insistence of the Vatican side.

While calling upon "the parts involved in the conflict" to engage in dialogue, the declaration did not identify the conflict's sides. Nor did it say a word about the role of Russia. The text paints Russia in bright colors, as a country with "unprecedented renewal of the Christian faith." In contrast to it, Ukraine is painted in dark colors, as a country in "deep economic and humanitarian crisis." This counterposition of the two countries is coherent with the message propagated by the Russian media. These and other words that have been said and that have not been said in the Havana declaration embarrassed many people in Ukraine. Many of them were Greek Catholics.

In parallel to producing statements, the Catholic Church developed a significant humanitarian mission in Ukraine. Pope Francis initiated a project called "Pope for Ukraine." ${ }^{31}$ He donated personally to the charitable fund and asked that Catholic parishes throughout Europe take up special collections for the same purpose. This fund, together with other Catholic charitable missions in Ukraine, offers humanitarian aid to the internally displaced persons and to those civilians who remain in the war zone. There were also visits of senior Catholic hierarchs to Ukraine, with the mission to support charitable activities. This was one of the purposes of Pietro Cardinal Parolin, the Vatican's Secretary of state, to come to Ukraine in June 2016. It should also be noted that the Catholic charitable organizations have operated on both sides of the conflict.

\section{Reactions from the World Council of Churches}

Christian churches usually hesitate to make explicit comments on political developments. In contrast to them, the World Council of Churches (WCC), which connects most of them to an ecumenical network, is always outspoken about political events, especially when they involve violence. However, just as in the case of the war

29 "Full Text of Joint Declaration Signed by Pope Francis and Patriarch Kirill," Article 26, Catholic

News Agency, February 12, 2016, accessed December 5, 2020, https://tinyurl.com/y6y7zd47.

"Full Text of Joint Declaration Signed by Pope Francis and Patriarch Kirill," Article 9.

31 “Pope for Ukraine' Project," Dicastery for Promoting Integral Human Development, November 18, 2018, accessed December 5, 2020, https://tinyurl.com/yywkx6m7. 
in Georgia, the WCC remained disturbingly silent about the drama that evolved in the East of Ukraine. Not a single word came from official spokespersons of this ecumenical organization for a long time.

The silence was broken only when the Malaysian Airlines Boeing was downed on July 17, 2014. Then, WCC Associate General Secretary Isabel Apawo Phiri promulgated a message of solidarity addressed to Dutch churches. In the message, there was a vague reference to "justice and righteousness": "This call demands our concern for all those who are deprived of their inherent and inalienable rights and dignity, of fullness of life and equal justice." ${ }^{22}$ Nevertheless, the message failed to provide justice or to hint at why this catastrophe happened. There was a reference to Russia in the message but in a positive light. It was stated that the message was sent in response to the call for solidarity from "member churches in Russia."

The WCC addressed the war in Ukraine for the first time only in February 2015, one year after it began. The message came from WCC Acting General Secretary Georges Lemopoulos, who also represented the Ecumenical Patriarchate in the organization. It endorsed the agreement of a ceasefire. There were many such agreements about a ceasefire in Ukraine, not one ever being kept, including the one to which the message referred. The WCC took the opportunity of one such agreement to address the Ukrainian situation:

The World Council of Churches welcomes the announcement yesterday of the ceasefire agreement for eastern Ukraine negotiated in Minsk. We express our sincere appreciation to all parties to these negotiations for this first step together towards peace, and to the leaders of Germany and France for their facilitation of the negotiations. The deaths and damage - and the confrontation and distrust within the international community — resulting from the conflict in Ukraine must be brought to an end. The elements of the new ceasefire agreement offer building blocks for a peaceful and principled resolution of the situation. A delegation organized by the WCC is expected to visit Ukraine in March, at which time we hope to see tangible signs of progress towards sustainable peace, and to accompany and strengthen that progress. In the meantime, the WCC urges all parties to the conflict to continue their steps towards peace, to maintain a commitment to dialogue and diplomacy, and to refrain from further violence that only can cause greater human suffering in Ukraine and deepen the rift in the social and political fabric of the region and in the wider international community. ${ }^{33}$ 
The statement, thus, announced a visit of a WCC delegation to Ukraine. The visit indeed took place from March 17 to 20, 2015. The delegation had a high profile, as it included WCC General Secretary Olav Fykse Tveit. It also included Rev. Karin van den Broeke from the Protestant Church in the Netherlands, Metropolitan Gennadios of Sassima from the Ecumenical Patriarchate, Catherine Gordon from the Presbyterian Church in the United States, Archpriest Mikhail Goundiaev from the Moscow Patriarchate, Bishop Christopher Hill from the Church of England, who at that time was also president of the Conference of European Churches, Bishop Jan Janssen from the Evangelical Lutheran Church in Oldenburg, Germany, and Archbishop Emeritus Anders Wejryd from the Church of Sweden.

Two members of the delegation visited the East of the country and met with people there. Some other members also visited a shelter for internally displaced persons near Kyiv. There were also two official meetings: one with the Ukrainian Orthodox Church (Moscow Patriarchate) and the other with the All-Ukrainian Council of Churches and Religious Organizations. Following the visit, the delegation published a communique, which included the following statements:

The delegation sought to express solidarity with the churches and people of Ukraine in the context of the conflict in the eastern part of the country following the 2013-2014 Maidan events. Further, the delegation came to listen to the experiences and perspectives of the churches and other partners in Ukraine, and to discern ways in which the WCC and the ecumenical movement might be able to support and strengthen efforts by Ukrainian churches and faith communities to promote an end to conflict and a just peace and reconciliation in Ukraine. The visit was facilitated by the WCC's member church in Ukraine, the Ukrainian Orthodox Church (Moscow Patriarchate), to whom we express our sincere appreciation.

During this visit, the delegation heard direct testimonies from church leaders and state representatives concerning the severe humanitarian impact of the violence in the affected regions. Delegation members had the opportunity to visit a displaced persons' shelter in Kiev and were able to encounter people who had been obliged to flee from the fighting. Delegation members were also able to travel close to the conflict zone, near Lisichansk, and to witness for themselves the destruction and disruption resulting from the crisis. The delegation also heard of the central role being played by churches in providing humanitarian aid in the affected regions, though the unmet needs still remain very great. Collectively, these experiences have underlined the critical situation for the people and communities most directly affected, the urgent need to increase humanitarian assistance to them, and 
the necessity of resolving this conflict in order to prevent even worse human suffering.

During this visit, the delegation has heard different perspectives on the origins of the conflict. In any event, the delegation is convinced of the potential of the churches and faith communities of Ukraine to play a lead role in transcending the competing nationalisms that predispose groups toward conflict, in addressing the social, economic and humanitarian needs that have been compounded by the fighting, and in promoting unity and reconciliation among all people of Ukraine. ${ }^{34}$

The text of the communique, on the one hand, acknowledges the vast humanitarian crisis caused by the conflict. On the other hand, its interpretation of the conflict is disappointingly close to some points of Russian propaganda. Thus, it has presented the war as a clash of "competing nationalisms." Such an interpretation, however, misses the essence of what happened in Ukraine during the Maidan and its aftermath. The Revolution of Dignity was not a nationalist insurgence but a struggle of civil society for the rule of law and against corruption. The majority of the people who fight on the Ukrainian side in the East of the country are Russian speaking and are not Ukrainian nationalists. The Russian propaganda, however, presents them as nationalists, and the WCC communique repeats this point.

The communique repeated another point of the Russian propaganda, namely that the Ukrainian Orthodox Church under the Moscow Patriarchate represents a key to bringing peace to Ukraine. In fact, this church failed even to acknowledge that there is a war. Regarding this, the document states:

The Ukrainian Orthodox Church (UOC) has a key role to play in the search for peace, unity and reconciliation. As the majority church in Ukraine - with congregations in all parts of the country and on both sides of the line of conflict — and having officially declared and reiterated its commitment to the territorial integrity and unity of Ukraine, the UOC has a special capacity and leadership responsibility in this regard. ${ }^{35}$

Many Christians in Ukraine were upset by the communique and suspected anti-Ukrainian bias in its statements. The delegation promised "to promote a more adequate humanitarian response to the human suffering resulting from the conflict, and to support and strengthen the efforts of the churches and faith communities of Ukraine for justice and peace." This promise was not fulfilled, however, because, after

“Communiqué by WCC Delegation to Ukraine," World Council of Churches, March 20, 2015, accessed December 5, 2020, https://tinyurl.com/y3nqnmov. 
the communique in March 2015, not a single statement on the war in Ukraine appeared on the website of the WCC. There were also no reactions from the WCC to other humanitarian issues connected with Ukraine, such as Ukrainian political prisoners in Russia, to which the international community and individual churches responded with vigor and criticism.

\section{Ukrainian Autocephaly as a Reaction to the War}

Many Christians in Ukraine were astonished or even shocked by the silence or misleading messages from the Orthodox, Catholic, and other churches, as well as from ecumenical organizations such as the WCC. At the same time, they were not surprised that the Russian church endorsed the aggression. For many, in the first place, this church was behind it, in the capacity of an ideological partner of the Kremlin. The profound involvement of the Moscow Patriarchate in the Russian aggression against Ukraine created a powerful momentum for the Ukrainian Orthodox faithful to seek their ecclesial independence from Moscow.

The initial momentum for Ukrainian autocephaly came from the faithful, subsequently facilitated by the Ukrainian state, and eventually fulfilled by the Ecumenical Patriarchate. For the Ukrainian state, the issue of the ecclesial independence of Ukraine was not only ecclesiastical but also political. The Russian Orthodox Church directly and through its outpost in Ukraine, the Ukrainian Orthodox Church, systematically weakened Ukrainian resistance to the Kremlin and sometimes overtly promoted the anti-Ukrainian agenda of the latter. Besides this, Ukrainian President Petro Poroshenko, who became a protagonist of Ukrainian autocephaly, hoped to improve his political support in the upcoming presidential elections in the spring of 2019.

For the Ecumenical Patriarchate, it seems, the issue was minimally political and mostly pastoral. Millions of Ukrainians, who associated themselves with the noncanonical Orthodox churches: the Kyiv Patriarchate and the Ukrainian Autocephalous Orthodox Church, were regarded by the rest of the Orthodox world as schismatics. Autocephaly was the only way for them to be reconciled with the rest of global Orthodoxy. The Ecumenical Patriarchate is an institution in the Orthodox Church, most appropriate for granting autocephaly. This church also demonstrated the most compassion for the sensitivities of the Ukrainian people. It more than any other church seemed to acknowledge the reality of the Russian aggression against Ukraine. Although Constantinople did not openly condemn this aggression and instead used euphemisms to express its concerns, even those euphemisms were appreciated in Ukraine. The most eloquent and powerful message of support for the Ukrainian people was granting autocephaly to their Orthodox church.

The decision of the Ecumenical Patriarchate was announced by President Poroshenko during his meeting with the heads of political factions in the Ukrainian Parliament on April 17, 2018. ${ }^{36}$ Poroshenko informed them about his visit to the

36 Petro Poroshenko, "Napysav ofitsiine zvernennia do Vselenskoho Patriarkha iz prokhanniam nadaty Tomos [I Have Written an Official Appeal to Ecumenical Patriarch Asking Him to Grant 
residence of the Ecumenical Patriarch in Istanbul during the week after the Orthodox Easter (April 8), where he had conversations with Patriarch Bartholomew and the members of the Synod. They announced to him their decision to proceed with granting the Ukrainian church autocephaly.

Upon his return to Ukraine, President Poroshenko met with the hierarchs of all Orthodox churches in Ukraine and asked for their support of his initiative. The Kyiv Patriarchate and the UOAC unanimously endorsed the President and promulgated official requests to the Ecumenical Patriarchate. The primate of the UOC MP Metropolitan Onufriy refused to support the initiative. Nevertheless, some bishops from his church agreed to participate in the process, even though their names were not disclosed. After these consultations, President Poroshenko sent to Istanbul his own official request to proceed with autocephaly. On April 19, the President asked the Parliament to support his request, and the Rada passed a relevant decision with a majority of votes. ${ }^{37}$ Petro Poroshenko, thus, became the primary mediator for the Ukrainian churches and political bodies in their communication with the Ecumenical Patriarchate. He swiftly secured formal support by the Ukrainian Parliament and most Ukrainian churches, with the UOC predictably abstaining.

Many in Ukraine believed at that time that autocephaly would be granted soon, by the end of spring or the latest in July, when the Ukrainian churches would celebrate the 1o3oth anniversary of the baptism of Kyiv. However, the relevant decisions of the Ecumenical Patriarchate were taken only during fall 2018. In the first days of September, from the ist to the 3 rd, a Synaxis of bishops from the Ecumenical Patriarchate was held in Istanbul. The role of this institution is rather advisory, but it usually convenes prior to the Holy Synod making its most important decisions. In September 2018, the Synaxis was assembled in the wake of the decision on Ukrainian autocephaly. On the first day of the Synaxis, its delegates listened to papers and participated in discussions relevant to the Ukrainian situation. In particular, its historical background, as well as the right of the Ecumenical Patriarchate to grant autocephaly and entertain appeals from other churches, were in the focus of deliberations by the Synaxis.

Soon after the Synaxis accomplished its work, on September 7, the Secretariat of the Holy Synod of the Ecumenical Patriarchate issued a statement about appointing two Patriarchal exarchs to Ukraine. ${ }^{38}$ They were Archbishop Daniel of Pamphilon from the United States and Bishop Ilarion of Edmonton from Canada. The mission of exarchs in the Ecumenical Patriarchate is similar to the mission of legates in the Catholic church. They represent the Patriarch and give account to him. They cannot

a Tomos]," Facebook, April 17, 2018, accessed December 5, 2020, https://tinyurl.com/y6tr28yf.

37 Ukrainian Parliament Resolution 2410-VIII, "Pro pidtrymku zvernennia Prezydenta Ukrainy do Vselenskoho Patriarkha Varfolomiia pro nadannia Tomosu pro avtokefaliiu Pravoslavnoi Tserkvy v Ukraini [On the Support for the President's of Ukraine Appeal to Ecumenical Patriarch Bartholomew on Granting a Tomos of Autocephaly to the Orthodox Church of Ukraine]," April 19, 2018, accessed December 5, 2020, https://tinyurl.com/yym4lcsw.

38 Ecumenical Patriarchate, "Announcement," Facebook, September 7, 2018, accessed December 5, 2020, https://tinyurl.com/y38cxaf9. 
act by their own authority and do not exercise the power of a diocesan bishop in the places to where they have been sent. A particular mission of the exarchs in Ukraine was to prepare the unifying council of the church.

The exarchs who visited Ukraine returned with their report to the Holy Synod, which held its session on October 9-11. Many in Ukraine expected that the Synod at this session would grant a Tomos of Ukrainian autocephaly. These expectations were fulfilled only partially. According to the communique published by the Ecumenical Patriarchate, ${ }^{39}$ it decided to take the following steps. The most important was to declare that the faithful of the non-canonical churches "have been restored to communion with the Church." This declaration meant the end of the schism that had existed in Ukraine since 1992.

The Synod in Constantinople also annulled the document of 1686 that had granted the church of Moscow temporarily and conditionally, according to Constantinople, management over the Metropolia of Kyiv. This effectively restored Constantinople's canonical jurisdiction over Ukraine in the form of a Metropolia. The Ukrainian church became a canonical structure similar to the one that had been established in the 1oth century and existed until 1686. The decision of the Ecumenical Patriarchate also meant that Constantinople does not recognize any existent jurisdiction in Ukraine except its own. Both the Kyiv Patriarchate and the UAOC were supposed to abolish themselves and to establish a new ecclesial group, which would receive recognition and independence from Constantinople. Simultaneously, Constantinople made it clear that the Ukrainian Orthodox Church under the Moscow Patriarchate ceased to exist. The Ecumenical Patriarch effectively announced this in his letter to Metropolitan Onufriy on October 12, the next day after the Synod in Constantinople. In his letter, Patriarch Bartholomew acknowledged Metropolitan Onufriy as the bishop of Kyiv by concession. He also warned him that after the new primate of the Ukrainian church would be elected the Metropolitan of Kyiv, Onufriy would not be able to hold this title. Onufriy, reportedly, did not respond to the letter and sent it back to Istanbul. ${ }^{40}$

By the decision of the same Synodal session in Constantinople, the primates of the Kyiv Patriarchate and UAOC, Filaret and Makariy respectively, were restored to the ranks they had before they were deposed by Moscow. Constantinople did this in the frame of its right to entertain appeals from other jurisdictions. The Synodal session also recognized the consecrations of bishops made in the two non-canonical jurisdictions.

At its last session in 2018, on November 27-29, the Synod of the Ecumenical Patriarchate made another step towards granting autocephaly to the Ukrainian church.

39 Ecumenical Patriarchate's Holy and Sacred Synod, "Announcement," The Ecumenical Patriarchate, October 11, 2018, accessed December 5, 2020, https://tinyurl.com/y3v2vy4g.

40 "Blazhennishyi Mytropolyt Onufriy povernuv lyst Patriarkha Varfolomiia nazad u Stambul [His Beatitude Metropolitan Onufriy Returned a Letter From Patriarch Bartholomew Back to Istanbul]," Ukrainska Pravoslavna Tserkva, December 8, 2018, accessed December 5, 2020, https://tinyurl.com/y39y4opm. 
It approved the draft of a Constitutional charter (Statute) for the new church. ${ }^{41}$ The draft was based on the Constitutional Charter of the Orthodox Church of Greece. It was only a draft, which could be modified, if necessary, and then accepted by the Ukrainian bishops. The November session of the Synod in Istanbul also approved the draft of the Ukrainian Tomos. At the same time, the Tomos was not yet published or promulgated.

The Tomos would be granted to the new church in Ukraine, which had yet to establish itself. The so-called unifying council, where the new church was established, took place in the historical St. Sophia Cathedral in Kyiv on December 15, 2018, under the presidency of the exarch from the Ecumenical Patriarchate, Metropolitan Emmanuel of France. On the eve of the council, the Kyiv Patriarchate and the UAOC disestablished themselves. All their bishops, plus two bishops from the Ukrainian Orthodox Church under the Moscow Patriarchate, took part in the council, now in the new capacity of the bishops of the Ecumenical Patriarchate. At the council, the Statute of the new church was adopted, and its new primate elected: Metropolitan Epiphaniy Dumenko. The new church named itself The Orthodox Church of Ukraine.

On January 6, 2019, Metropolitan Epiphaniy, accompanied by President Petro Poroshenko, visited Istanbul. At the residence of the Ecumenical Patriarch at Phanar, he received the Tomos for Ukrainian autocephaly. The document was first signed by Patriarch Bartholomew, and later by members of the Holy Synod of the Church of Constantinople. This solemn act finalized the process of granting the Ukrainian church its canonical independence (autocephaly).

\section{The Reception of Ukrainian Autocephaly in the Orthodox World}

The rules of the Panorthodox Commonwealth require that a new autocephalous church should be accepted by other autocephalous churches. When the Orthodox Church of Ukraine received its Tomos in January 2019, only the Ecumenical Patriarchate recognized it. Other churches hesitated to do so. In this way, they effectively demonstrated their attitude to the war in Ukraine. Given that granting autocephaly was a reaction to the war, the delayed recognition of this autocephaly by other local churches meant that they continued keeping a blind eye to the war. The situation changed after the Ecumenical Patriarchate pressed some local churches to recognize the Orthodox Church of Ukraine. By the end of 2020, the Church of Greece, the Patriarchate of Alexandria, and the Church of Cyprus recognized the autocephalous church in Ukraine.

The reaction of the Russian Orthodox Church to the decisions of the mentioned churches to recognize Ukrainian autocephaly was predictable. It both backed the war and openly opposed Ukrainian autocephaly. During his visit to Phanar at the end of August 2018, the Patriarch of Moscow Kirill tried to convince Patriarch Bartholomew not to proceed with the Tomos. After this attempt failed, the Holy Synod of the Russian Orthodox Church at its extraordinary session on September 8 declared "the decision 
of the Holy Synod of the Patriarchate of Constantinople... as a severe violation of church canons." ${ }^{2}$ On September 14, at another extraordinary session, the same Synod decided "to suspend the liturgical prayerful commemoration of Patriarch Bartholomew of Constantinople" and "the con-celebration with hierarchs of the Patriarchate of Constantinople." 43 After the decision of the Ecumenical Patriarchate on October 11 to end the schism in Ukrainian Orthodoxy, the reaction of Moscow was somewhat, not much, stronger. On October 15, the Synod of the Russian church ceased Eucharistic communion with the Ecumenical Patriarchate. ${ }^{44}$ However, it did not proceed toward a fully-fledged schism.

The Ukrainian Orthodox Church under the Moscow Patriarchate acted in complete coherence with the Moscow Patriarchate and adopted similar decisions. Its council of bishops adopted a decision in Kyiv to break communion with the Ecumenical Patriarchate on November 13, 2018.45 The council was convened for the first time following Metropolitan Onufriy's election as primate of the church to discuss the invitation by President Poroshenko to meet with bishops of the UOC. The bishops decided to decline the invitation. ${ }^{46}$ They thus refused to engage in conversation with Ukrainian political authorities.

In contrast, the Moscow Patriarchate secured the support of the Russian state in rebuking Ukrainian autocephaly. As a result, for example, Russian Minister of Foreign Affairs Sergey Lavrov made the following statement in his interview to RT France, Paris Match, and Figaro:

As regards the church problems, the interference [of the state] in the life of the church is prohibited by law in Ukraine, Russia, and, I hope, in any other normal state. However, when the special representative of the USA on questions of church relations openly welcomes the decision of Patriarch Bartholomew, when K. Volker, ${ }^{47}$

42 "Zhurnal zasedaniia Sviashchennogo Sinoda № 68 [Minutes of the Holy Synod, Minute No. 68]," Russkaia Pravoslavnaia Tserkov, September 8, 2018, accessed December 5, 2020, https://tinyurl.com/yxqwh4qf.

"Minutes of the Holy Synod, Minute No. 69," Russian Orthodox Church, September 14, 2018, accessed December 5, 2020, https://tinyurl.com/y23bseyt.

"Zhurnal zasedaniia Sviashchennogo Sinoda № 71 [Minutes of the Holy Synod, Minute No. 71]," Russkaia Pravoslavnaia Tserkov, October 15, 2018, accessed December 5, 2020, https://tinyurl. com/y356aymg. "Resolution of the Council of Bishops of the Ukrainian Orthodox Church of November 13, 2018," Ukrainian Orthodox Church, November 14, 2018, accessed December 5, 2020, https://tinyurl. com/yxdfeowm.

46 See "Statement of Council of Bishops of Ukrainian Orthodox Church Regarding Meeting with President of Ukraine P. O. Poroshenko," Ukrainian Orthodox Church, November 14, 2018, accessed December 5, 2020, https://tinyurl.com/y2vlth3h. 
who is supposed, on behalf of the USA, to contribute to Ukrainian normalization on the basis of the Minsk agreements, makes his statements about these processes, in this case we say: if the shoe fits, wear it. 48

The irony about this statement is that it represented clear political interference in church affairs. Moreover, the statement by Lavrov followed a meeting of Russian President Vladimir Putin with permanent members of the Security Council on October 12, including the Minister of Defense, directors of the FSB and the Foreign Intelligence Service. This meeting was dedicated exclusively to the Ukrainian church issue. It seems the issue had become of extreme importance in Russian politics.

While Russian reactions to the Ukrainian Tomos were predictable, some other local churches disappointed with their statements, which anyone hardly expected them to make, on the same issue. One such statement came from the Orthodox Church in America (OCA). This church, which was granted autocephaly by the Moscow Patriarchate in 1970, struggles with the same issue of the lack of recognition from other churches. However, it did not demonstrate any empathy with the Ukrainian church, which found itself in the same canonical situation. Instead, on January 28, 2019, the Synod of the OCA issued a statement, which effectively called to ignore decisions of the Ecumenical Patriarchate regarding Ukraine. ${ }^{49}$

Even more contradictory was the decision of the Orthodox Church of Poland. This church was granted autocephaly in 1924 by the Ecumenical Patriarchate on the same grounds that Constantinople used to grant autocephaly to the Orthodox Church of Ukraine. Yet, the Church of Poland ignored these grounds and thus undermined its own autocephaly. On November 15, 2018, the council of bishops of the Orthodox Church of Poland took a decision regarding the Orthodox Church of Ukraine, by which it refused to recognize all the acts that the Ecumenical Patriarchate undertook regarding Ukraine.50

48 “Interviu Ministra inostrannykh del Rossii S. V. Lavrova 'RT Frans,' 'Pari Match' i ‘Figaro' [Interview of the Minister of Foreign Affairs of Russia S. V. Lavrov to RT France, Paris Match, and Figaro]," Ministerstvo inostrannykh del Rossiiskoi Federatsii, October 18, 2018, accessed December 5, 2020, https://tinyurl.com/y4jo62bm.

"Holy Synod of Bishops Issues Archpastoral Letter on Ukraine," Orthodox Church in America, January 28, 2019, accessed December 5, 2020, https://tinyurl.com/y4xj6w2p.

“Osoby pozbawione święceń biskupich i kapłańskich nie mogą być liderami przy wprowadzaniu pokoju w Prawosławnym Kościele Ukraińskim. Ich działania powodują jeszcze większy zamęt i zgorszenie... Święty Sobór Biskupów zabrania duchownym Polskiego Autokefalicznego Kościoła Prawosławnego wchodzenia w liturgiczno-modlitewne kontakty z 'duchownymi' tzw. 'Patriarchatu Kijowskiego' i tzw. 'Autokefalicznej Cerkwi', które w dotychczasowych działaniach uczyniły wiele zła." See "Komunikat Kancelarii Św. Soboru Biskupów," Oficjalna Strona Polskiego Autokefalicznego Kościoła Prawosławnego, November 15, 2018, accessed December 5, 2020, https://tinyurl.com/y55bu6fg. 


\section{Reactions of the Vatican to the Tomos}

The Vatican considered the Ukrainian situation as intra-Orthodox and therefore refused to express any official standpoint in its regards. The Ukrainian Greek Catholic Church (UGCC), which informally supported Ukrainian autocephaly, officially remained neutral. Thus, after he met with Pope Francis on July 3, 2018, the Primate of the UGCC, Archbishop Sviatoslav, came out with the following official statement:

We evaluate positively the efforts to overcome division in Ukrainian Orthodoxy, in accordance with the ancient principle salus animarum lex suprema est. At the same time, we consider these processes an internal affair of the Orthodox side and in no case interfere with these processes and do not participate in them. We are convinced that secular authorities are obliged to provide the necessary conditions for the free development of all churches in our state, and it is unacceptable if they treat any Church as established. ${ }^{51}$

\section{Conclusions}

Christian churches of different denominations in different countries of the world, in most cases, failed to acknowledge the sufferings of the Ukrainian people caused by war. They also failed to condemn the role of Russia in the war. Their standpoint regarding the war and Russia has been much weaker than the positions of most international organizations and national governments in the West. The only church that adequately addressed the Ukrainian issue is the Ecumenical Patriarchate. It has demonstrated genuine compassion for the suffering Ukrainian people by granting autocephaly to their church.

Alarming is the silence of many local Orthodox churches regarding the war in Ukraine and their adverse reactions to the initiative of the Ecumenical Patriarchate. Not only that many of them have appeased Russian politics, but they have also been quick to rebuke the autocephaly of the Orthodox Church of Ukraine. Some of them, in this way, effectively undermined their own autocephaly. Among the reasons for such appalling blindness about the war in Ukraine is the deficiency of Orthodox social ethics. In contrast to them, the Vatican and international ecumenical organizations have strong social ethics. Still, they have not done enough to properly acknowledge the perpetrators in the Ukrainian war and the humanitarian crisis it has caused.

$51 \quad$ "Sviatishyi Otets podiakuvav UGKTs za svidchennia yednosti Khrystovoi Tserkvy [His Holiness Thanked the UGCC for Its Witness of Unity of Christ's Church]," Informatsiinyi resurs Ukrainskoi Hreko-Katolytskoi Tserkvy, July 3, 2018, accessed December 5, 2020, https://tinyurl. com/yzeupykt. 


\section{Bibliography}

"Apostolic Journey of His Holiness Pope Francis to Turkey: Ecumenical Blessing and Singing of the Common Declaration." The Holy See, November 30, 2014. Accessed December 5, 2020. https://tinyurl.com/y2bagdoj.

"Blazhennishyi Mytropolyt Onufriy povernuv lyst Patriarkha Varfolomiia nazad u Stambul [His Beatitude Metropolitan Onufriy Returned a Letter From Patriarch Bartholomew Back to Istanbul]." Ukrainska Pravoslavna Tserkva, December 8, 2018. Accessed December 5, 2020. https://tinyurl.com/y39y4opm.

"Communiqué by WCC Delegation to Ukraine." World Council of Churches, March 20 , 2015. Accessed December 5, 2020. https://tinyurl.com/y3nqnmov.

Ecumenical Patriarchate. "Announcement." Facebook, September 7, 2018. Accessed December 5, 2020. https://tinyurl.com/y38cxaf9.

Ecumenical Patriarchate's Holy and Sacred Synod. "Announcement." The Ecumenical Patriarchate, October 11, 2018. Accessed December 5, 2020. https://tinyurl.com/ y3v2vy4g.

Ecumenical Patriarchate's Holy and Sacred Synod. "Communiqué." The Ecumenical Patriarchate, November 29, 2018. Accessed December 5, 2020. https://tinyurl.com/ y3u3397g.

"EU Restrictive Measures in Response to the Crisis in Ukraine." Delegation of the European Union to Russia, August 10, 2017. Accessed December 5, 2020. https:// tinyurl.com/y6noddxy.

European Parliament Resolution 2014/2841 (RSP). On the Situation in Ukraine and the State of Play of EU-Russia Relations, September 18, 2014, P8_TA(2014)oo25. Accessed December 5, 2020. https://tinyurl.com/y2afpumg.

European Parliament Resolution 2016/2556 (RSP). On the Human Rights Situation in Crimea, in Particular of the Crimean Tatars, February 4, 2016, P8_TA(2016)oo43. Accessed December 5, 2020. https://tinyurl.com/y48zahgf.

European Parliament Resolution 2018/2754(RSP). On Russia, Notably the Case of Ukrainian Political Prisoner Oleg Sentsov, June 14, 2018, P8_TA(2018)o259. Accessed December 5, 2020. https://tinyurl.com/yxo8v8zv.

Fotolitopys UPTs. "Zvernennia Mytropolyta Onufriia Mistsebliustytelia Kyivskoi mytropolychoi kafedry [The Address of Metropolitan Onufriy, Acting Head of the Kyivan See]." YouTube Video, 5:O2, March 2, 2014. https://tinyurl.com/y279ngvw.

"Full Text of Joint Declaration Signed by Pope Francis and Patriarch Kirill." Catholic News Agency, February 12, 2016. Accessed December 5, 2020. https://tinyurl.com/ y6y7zd47.

"Holy Synod of Bishops Issues Archpastoral Letter on Ukraine." Orthodox Church in America, January 28, 2019. Accessed December 5, 2020. https://tinyurl.com/ y4xj6w2p.

Hromadske. "Yepyskop Klyment: Vladyka Pavlo ne kupuvav sobi avto ta maietoktse pozhertvy [Bishop Klyment: Bishop Pavlo Did Not Buy Himself a Car and an 
Estate-These are Donations].” YouTube Video, 55:35, October 8, 2015. Accessed December 5, 2020. https://tinyurl.com/yxgon8zv.

"Interviu Ministra inostrannykh del Rossii S. V. Lavrova 'RT Frans,' 'Pari Match' i 'Figaro' [Interview of the Minister of Foreign Affairs of Russia S. V. Lavrov Given to RT France, Paris Match, and Figaro]." Ministerstvo inostrannykh del Rossiiskoi Federatsii, October 18, 2018. Accessed December 5, 2020. https://tinyurl.com/y4jo62bm.

"Komunikat Kancelarii Św. Soboru Biskupów." Oficjalna Strona Polskiego Autokefalicznego Kościoła Prawostawnego, November 15, 2018. Accessed December 5, 2020. https:// tinyurl.com/y55bu6fg.

"MH17: The Netherlands and Australia Hold Russia Responsible." Government of the Netherlands, May 25, 2018. Accessed December 5, 2020. https://tinyurl.com/ y38nhen2.

Miller, Christopher. "13 tysiach: ofitsiini dani OON shchodo zahyblykh u viini na Donbasi [13 Thousand: Official UN Data of Those Killed on the War in the Donbas]." Radio Svoboda, 26 February, 2019. Accessed December 5, 2020. https://tinyurl.com/ y6xw27w9.

"Minutes of the Holy Synod, Minute No. 69." Russian Orthodox Church, September 14, 2018. Accessed December 5, 2020. https://tinyurl.com/y23bseyt.

"Molitva o prekrashchenii mezhdousobnyia brani na Bozhestvennoi liturgii po suguboi ektenii chtomaia [A Prayer on the Termination of Fratricide for the Divine Liturgy]." Russkaia Pravoslavnaia Tserkov, June 17, 2014. Accessed December 5, 2020. https://tinyurl.com/y6xcfwnx.

"Pope Decries 'Fratricide' Conflict in Ukraine and Appeals for Dialogue." Vatican Radio, February 4, 2015. Accessed December 5, 2020. https://tinyurl.com/yxsuzod7.

“'Pope for Ukraine' Project.' Dicastery for Promoting Integral Human Development, November 18, 2018. Accessed December 5, 2020. https://tinyurl.com/yywkx6m7.

Poroshenko, Petro. "Napysav ofitsiine zvernennia do Vselenskoho Patriarkha iz prokhanniam nadaty Tomos [I Have Written an Official Appeal to the Ecumenical Patriarch Asking Him to Grant a Tomos]." Facebook, April 17, 2018. Accessed December 5, 2020. https://tinyurl.com/yxl4yjml.

"Rada Tserkov hotuie zvernennia na pidtrymku ukrainskikh viazniv Kremlia [The Council of Churches is Preparing an Appeal in Support of Ukrainian Kremlin Prisoners]." Religion in Ukraine, June 13, 2018. Accessed December 5, 2020. https:// tinyurl.com/y2puawnu.

"Rada Tserkov zaklykaie vidnovyty konstytutsiinyi lad ta povnotu prav i svobod hromadian (zaiava) [The Council of Churches Calls for the Restoration of the Constitutional Order and the Fullness of Citizens' Rights and Freedoms (Statement)]." Instytut Relihiinoi Svobody, January 25, 2014. Accessed December 5, 2020. https://tinyurl.com/y4ckzjno.

"Rada Tserkov zaklykaie zvilnyty zaruchnykiv z polonu na Donbasi [The Council of Churches Calls for the Release of Hostages From Captivity in the Donbas]." VRTsIRO, September 8, 2016. Accessed December 5, 2020. https://tinyurl.com/ y6e6c9w9. 
"Resolution of the Council of Bishops of the Ukrainian Orthodox Church of November 13, 2018." Ukrainian Orthodox Church, November 14, 2018. Accessed December 5, 2020. https://tinyurl.com/yxdfeowm.

"Solidarity Message for Dutch Churches over Malaysia Airlines Disaster." World Council of Churches, July 22, 2014. Accessed December 5, 2020. https://inyurl.com/ y6ect8mt.

"Statement of Council of Bishops of Ukrainian Orthodox Church Regarding Meeting with President of Ukraine P. O. Poroshenko." Ukrainian Orthodox Church, November 14, 2018. Accessed December 5, 2020. https://tinyurl.com/y2vlth3h.

"Statement on Ukraine Ceasefire Agreement." World Council of Churches, February 13, 2015. Accessed December 5, 2020. https://tinyurl.com/yyjz8sqk.

"Sviatishyi Otets podiakuvav UGKTs za svidchennia yednosti Khrystovoi Tserkvy [His Holiness Thanked the UGCC for Its Witness of Unity of Christ's Church]." Informatsiinyi resurs Ukrainskoi Hreko-Katolytskoi Tserkvy, July 3, 2018. Accessed December 5, 2020. https://tinyurl.com/yzeupykt.

"Ukraine. Situation Report." United Nations Office for the Coordination of Humanitarian Affairs. Last updated on October 27, 2020. Accessed December 5, 2020, https:// tinyurl.com/y49o2qov.

Ukrainian Parliament Resolution 2410-VIII "Pro pidtrymku zvernennia Prezydenta Ukrainy do Vselenskoho Patriarkha Varfolomiia pro nadannia Tomosu pro avtokefaliiu Pravoslavnoi Tserkvy v Ukraini [On the Support for the President's of Ukraine Appeal to Ecumenical Patriarch Bartholomew on Granting a Tomos of Autocephaly to the Orthodox Church of Ukraine]," April 19, 2018. Accessed December 5, 2020. https://tinyurl.com/yym4lcsw.

UN General Assembly Resolution 68/262. Territorial Integrity of Ukraine, A/RES/68/262, March 27, 2014. Accessed December 5, 2020. https://tinyurl.com/y55fo8dz.

UN Security Council Draft Resolution S/2014/189. Accessed December 5, 2020. https:// tinyurl.com/yzolofpg.

UN Security Council Resolution 2166 (2014). S/RES/2166 (2014), July 21, 2014. Accessed December 5, 2020. https://tinyurl.com/yxvb5x36.

"Urbi et Orbi Message of His Holiness Pope Francis (Easter 2015)." The Holy See, April 5, 2015. Accessed December 5, 2020. https://tinyurl.com/y3tl5ght.

US House of Representatives. Resolution Affirming United States Support to the Nations of Ukraine, Georgia, and Moldova in Their Effort to Retain Political Sovereignty and Territorial Integrity, June 20, 2018. 115th Cong., 2nd sess. H. Res. 955. Accessed December 5, 2020. https://tinyurl.com/y2hhqoke.

"Zaiava Rady Tserkov shchodo rishennia Rosii pro viiskove vtorhnennia v Ukrainu [The Council of Churches Statement on Russia's Decision on the Military Invasion of Ukraine]." VRTsIRO, March 2, 2014. Accessed December 5, 2020. https://tinyurl. com/y43vsd72.

"Zaiava za pidsumkamy zustrichi z kerivnytstvom Verkhovnoi Rady Ukrainy [Statement Following the Meeting with the Leadership of the Verkhovna Rada of Ukraine]." 
VRTsIRO, February 26, 2014. Accessed December 5, 2020. https://tinyurl.com/ y6rgyam6.

"Zhurnal zasedaniia Sviashchennogo Sinoda No 68 [Minutes of the Holy Synod, Minute No. 68]." Russkaia Pravoslavnaia Tserkov, September 8, 2018. Accessed December 5, 2020. https://tinyurl.com/yxqwh4qf.

"Zhurnal zasedaniia Sviashchennogo Sinoda № 71 [Minutes of the Holy Synod, Minute No. 71]." Russkaia Pravoslavnaia Tserkov, October 15, 2018. Accessed December 5, 2020. https://tinyurl.com/y356aymg.

"Zvernennia Vseukrainskoi Rady Tserkov i relihiinykh orhanizatsii [Appeal of the AllUkrainian Council of Churches and Religious Organizations]." VRTsIRO, April 12, 2017. Accessed December 5, 2020. https://tinyurl.com/y2uep3dy.

"Zvernennia Vseukrainskoi Rady Tserkov i relihiinykh orhanizatsii pro oboviazok dopomohy u zakhysti Batkivshchyny [Appeal of the All-Ukrainian Council of Churches and Religious Organizations on the Obligation to Assist in the Defense of the Motherland]." VRTsIRO, February 10, 2015. Accessed December 5, 2020. https://tinyurl.com/y4ukkmh7.

"Zvernennia Vseukrainskoi Rady Tserkov na pidtrymku blahodiinytstva i volonterskoi dialnosti [Appeal of the All-Ukrainian Council of Churches and Religious Organizations for the Support of Charity and Volunteer Activity]." VRTsIRO, October 31, 2014. Accessed December 5, 2020. https://tinyurl.com/y5fdqgdx.

"Zvernennia Vseukrainskoi Rady Tserkov u zviazku z suspilno-politychnoiu sytuatsiieiu v Ukraini [Statement of the All-Ukrainian Council of Churches Regarding the Social and Political Situation in Ukraine]." VRTsIRO, December 10, 2013. Accessed December 5, 2020. https://tinyurl.com/y5y6pkal.

"Zvernennia Vseukrainskoi Rady Tserkov z nahody Dnia Sobornosti ta Svobody Ukrainy [Statement of the All-Ukrainian Council of Churches on the Occasion of Ukrainian Unity and Liberty Day]." VRTsIRO, January 22, 2014. Accessed December 5, 2020. https://tinyurl.com/yyqb6fkg.

\section{(7)}

Cyril Hovorun is a Professor of Ecclesiology, International Relations and Ecumenism at the Sankt Ignatios College, Stockholm School of Theology. A graduate of the Theological Academy in Kyiv and National University in Athens, he completed his doctoral studies at Durham University. He was Chairman of the Department for External Church Relations of the Ukrainian Orthodox Church, First Deputy Chairman of the Educational Committee of the Russian Orthodox Church, Research Fellow at Yale and Columbia Universities, Visiting Professor at the University of Münster in Germany, International Fellow at Chester Ronning Centre for the Study of Religion and Public Life at the University of Alberta in Canada, Director of the Huffington Ecumenical Institute at Loyola Marymount University in Los Angeles and Assistant Professor at the same university. He has published several books in different languages: Political Orthodoxies: The Unorthodoxies of the Church Coerced (Minneapolis: Fortress, 2018; Ukrainian 
translation published in 2019); Ukrainian Public Theology (Kyiv: Dukh i Litera, 2017, in Ukrainian), Scaffolds of the Church: Towards Poststructural Ecclesiology (Eugene, OR: Cascade, 2017; Ukrainian translation published in 2018); Wonders of the Panorthodox Council (Moscow: Christian Book Club, 2016, in Russian); Meta-Ecclesiology, Chronicles on Church Awareness (New York: Palgrave Macmillan, 2015; Ukrainian translation published in 2017); From Antioch to Xi'an: An Evolution of "Nestorianism" (Hong Kong: Chinese Orthodox Press, 2014, in Chinese); Will, Action and Freedom. Christological Controversies in the Seventh Century (Leiden, Boston: Brill, 2008). 